\title{
Work Ethic Based on Islamic Perspective
}

\author{
Abdul Chalim \\ Politeknik Negeri Malang, J1. Soekarno Hatta No. 9 Malang, Jawa Timur, Indonesia
}

\begin{abstract}
Moderate work ethics in a lifetime derived from the deficiency of religious understanding - that converge to ritualistic behavior and afterlife oriented that abandon the aspects of humankind. As Muslims within high-work ethics should have self-motivation, thinking skills, and performing positive things, not to satisfy quickly, tranquil, self-control, persistent, hard-working, and realize all we've done is part of worship. Work is an attempt actualization of self-humans to understand God's gift on earth. Work means continuity of human's duty as a God's caliph. The accomplished work means as a process of self-discovery, and so forth for pursuing results to fulfill the basic human needs. Work is a process to achieve purposes, so work ethics are essentials to be a cornerstone in the working process for everyone. Thus, the work results mean zero value if the process is in contrast to the natures or the established universal law (grace, truth, and integrity). Based on Islamic sight, work is a kind of faith expression, for whom with the completed value claims better. For Muslims, the supreme and highest value refers to work ethic is "intention". The intention for Muslims is an inspiration and motivation to become human beings who are professional at work. For someone that works with intentions are conscious of the commitment and awareness of self that is important at work, that is the good pleasure of God.
\end{abstract}

Keywords: Ethos, Work Ethic, Islam.

DOI: $10.7176 / \mathrm{JLPG} / 101-15$

Publication date:September $30^{\text {th }} 2020$

\section{Introduction}

The work ethics personally came out by the motivation that reflected on the life attitude that is fundamental to the work. Islamic perspective particularly states work ethic arising from the Islamic faith concerning the work that refers to the revelation and connection with the intellect. It is a source of motivation, inspiration, and value to build Islamic work ethics. This work ethic is dynamic and affects various factors at once. An example is an environmental and technological side. The framework of Islamic work ethics involves numerous factors and not only determined by some particular causes. Within Islamic perspectives, many passages are correlated with a mandate to work. In Surah, Al Jumu'ah states: " And when the Prayer is finished then may ye disperse through the land and seek of the Bounty of Allah: and celebrate the Praises of Allah often (and without stint): that ye may prosper." (Al Jumu'ah: 10) . Also in Surah At- Taubah explains: "And say: "Work (righteousness): soon will Allah observe your work and His apostle and the believers: soon will ye be brought back to the knower of what is hidden and what is open: then will He show you the truth of all that ye did.." (At- Taubah: 105).

From the previous passages, work ethics is a high obligation for Muslims. Islamic work ethics are mandatory on the morality of such faithfulness, liable, convince, living simply, tolerance, and keep the faith to God. Besides the previous explanation, we can refer that the basis of work ethic is the goal of human existence as the caliphate, who are mandatory to maintain life in purpose to achieve harmony and prosperity.

Work ethic in the Islamic perspective reflects the Islamic faith that fundamentally stands for faith. The faith and charity bond similar to the roots and tree, that are in separately. When it refers to faith, Islamic work ethics is the precise manifestation and becomes its parts. Faith characteristics distinguish into trust and practice as evidence that the conviction was working well. Work and charity are not contrary to the teachings of Islam. In other words, faith is the foundation, while the deed (work) is a consequence or the way to express. The faith built and born the deeds, and both are associated with human - God relationship and the human-human relationship and involving the implementation as the God's caliph, that taken from the guidance, Qur'an and Al-Hadith

\section{Work Ethics in Islamic Perspectives}

The term ethic described in the dictionary came from the ancient Greek (ethos) means as character or characters. The extent meaning covers characteristics and attitudes, habits, and beliefs that specify to a person or as an individual or a group of humans. Ethos particularly relates to terms of ethics and ethics that refer to the meaning of morals or good character, namely the quality of essential a person or group of people around the nation. Ethics also means soul typical of a group of humans, whom the typical soul of the evolving views of the people are on the good and the bad side, and that is ethical. (Nurcholis Madjid, 1992: 411).

Work is an attempt to actualize the human self to seek the gift on earth as the continuity of the meaning and task of the human caliphate. The accomplished work means as a process of self-discovery or, once seeking the results to meet the basic human needs. Work can figure as the process to obtain the results then the issue of ethics of work is fundamental to be a cornerstone of the process. The results have no value if the process contrast from 
the natures (grace, truth, and integrity).

For all accomplished work regards to the faith, the expression demanded the work ethics accomplished in the job was typical value, good as an idea or value as its operations. Each work that bond to Islamic value that is the embodiment of the ethos of the highest of the ethos that exists, that is the intention, such as commitment and awareness of themselves for someone in doing their job.

An intention performs personal judgment and decision that is related to the value refers to a certain value. Moreover, intention serves as a source of personal motive for someone to act. The Prophet Muhammad stated: "Indeed, every action depends on the intention, and for someone can only get according to what he intended". (HR Muslim from Umar bin Khattab).

Intentions for Muslims are an achievement that is to accomplished. If intention is in the highest pose (only for God's sake) then the goal will follow. In contrast, a lack of intention will affect the goal itself. For example, people working with purposes to praise by others then what he gets only the things that they desired at all. To prove intent or achieve the goal must involve the entire activities and capabilities that exist. Someone who does not have any intention is similar to no life purpose or in other words, he may not having faith. Therefore, the intention of humans is essentials. Another example, someone has the intention to study in college, then it is proven by preparing for the test with good arrangement and great planning. For others that have the intention to work, the inner feeling, and the spirit of seeking a job with earnestly he tried faithfully. Intentions as the value of the ideal can be determined by particular characteristics or indications, as proposed by Khursid Ahmad as follows:

a. Based on the principle of at-monotheism, which provides the basis of the relationship between humans and their Lord and fellow human beings.

b. Rububiyah, is the maintenance of natural resources according to the laws of kauniyah (natural law) or sunnatullah that apply to the universe.

c. Khilafah or caliph, namely laying position, functions and responsibilities in charge of man as an individual and people in social life that set by Allah that gives the basic moral and ethical to the role of human and people.

d. Tazkiyah, the purification of the results of work and wealth through the zakat, for the growth and survival of life and the life of man . (M. Rusli , 1992: 109-110)

The form of the value reflects on work ethics is refer to good deeds (Ihsan) that are work attitude purposes only to seek the pleasure of God with its implications, such as the work as expertise, professional and responsible. The good deeds may view as working with devotion, to optimize the work results, or by working it as well as possible and as perfect as possible. Further development of the Islamic work ethic premises methods praxis (practical) is as follows:

a. Conduct a social analysis to look for and find the foundations and objectives of the community at work.

b. Practicing the theological thought to gain an in-depth understanding in the clear form of the horizontal relationship such follow: Tazkiyah (purification), birr (goodness), ihsan (good deeds), fair, ta'awun (cooperative working) and roqobah (freeing human from slavery).

c. Conduct a specific work program to achieve fundamental work goals.

d. Planning the implementation with both participation between the owner and laborers by applying some particular ethos.

e. Action together that is based on the principle of Ta'awwun (cooperation)

(Dawan Raharjo, 1989: 156-161)

The work ethic for Muslims at the present time is deeply influenced by education, information, and communication. Because it needs to be developed an ethos of science knowledge and technology. The Islamic work ethic is not meant to exploit the source of the power of nature in accordance with the wishes desires passion and interest in the flesh of man, but the vital is manifest prosperity, as described in the Holy Qur'an Surrah Hud, verse 61 states: " To the Thamud People (We sent) Salih, one of their own brethren. He said: "O my people! Worship Allah. ye have no other god but Him. It is He Who hath produced you from the earth and settled you therein: then ask forgiveness of Him, and turn to Him (in repentance): for my Lord is (always) near, ready to answer". Creating happiness, as described in the Qur'an letter al- Ahzab verse 71 states: "That He may make your conduct whole and sound and forgive you your sins: He that obeys Allah and His Messenger, has already attained the highest achievement."

The previous explanation gives insightful knowledge that the characteristics of Muslims with work ethic define as follows:

a. Develop the principle of professional management.

b. Have a leadership spirit

c. Consider the decisions that are taken

d. Good time-management

e. Always strive towards goodness

f. Good money-management 
g. Have a strong willingness for good deeds

h. Have the motivation to be independent

i. Knowing Rahmatan lil ' Alamin (A mercy to all creation).

j. Long-life learner spirits

k. not to satisfy quickly, tranquil, self-control, persistent, and hard-working.

Need presumably to explain that the work ethics must always follow included therein, by this work is evidence of their faith and a barometer for the reward and the punishment. Every job should accommodate the final goal in the form of wages or rewards but the main goal is necessary to establish, to obtain the pleasure of God. The principle must be held firmly by Muslims so that the results of the work they are qualified and monumental throughout the ages. If the work requires the attitude of good thought, honest and trustworthy, the suitability of wages and not allowed to cheat, rob, ignoring something, and arbitrarily, the work must commit to the faith, have the motivation to run as earnest in work and always improve its social interaction. Besides that they have to develop ethics that relate to the problem of work become a tradition of work is based on Islamic principles.

\section{Work and its Application}

Work in the Islamic perspective does not just work, but means "work for work". In Islamic terms, work means to fulfill the call of God and His Apostle. Work is equal to worship. The essence of the work is the activity of a person to obtain God's gift which has been deployed and spread widely around the globe, which is hard-working. To obtain God's gift, the direction does not pass over His mandatory (Al-maghdub) but the straight direction (syirath al-mustaqim). As a result of the act that not pursuing the basic principle of god and humanity led to hesitation in the future days. The desired work by God and His Messenger are:

a. Good work is the work that can purify the mind and soul.

b. Straighten out the mind and character.

c. Expand the chance of virtue.

d. A medium to strengthen the relationship of brotherhood

e. Maintain a social life

f. A protector for ourselves that relate to beliefs, heritage, soul (pride), intellect, and wealth.

g. Work safely and doing good in nature.

h. Provide benefits for other

i. The work results not prohibited things (haram).

j. Work must be under the law of God (Holy Qur'an, the Sunnah of the Prophet and God's law)

$\mathrm{k}$. Work should start with good intentions.

Islam has accused lifeless acts and blocks the motion of tramps and restricts all the dependence forms of living to others, but Holy Qur'an highly praised to the people for being patient and hold themselves to not ask for others help in fulfilling the basic needs because of that will led to sets of problems and difficulties in a lifetime.

Imam Ibnul Jauzi said: No one is condemned as a lazy for certain conditions; first; abandoning his family and leaving his duty to manipulative act as surrendering fully to God and his life becomes a barrier to his family and others and set them in suffering, second; Thus was a humiliation which does not affect to someone except to lowly people and tramps, because human with dignity is not willing to lose the pride and abandon his life cause of laziness with the peripheral reasons such as abandonment that burdened with remarkable stupidity, because in particular circumstance person may not have a penny but they still have a chance and opportunity to work.

Muslims are considered to live well, persistent, eager, devote, hard-working to fulfill their basic needs, and also work for the future generation to live independently and not burden others. Those who are lazy will burden others, and beggars who have no dignity are the most disgraceful and banned by the faith. A hadith from Abdullah Ibn Umar stated that the Prophet said: the attitude of begging upon someone or in-person among you unless he may come to the God, while his face is flesh-less. Yusuf bin Asbath said that Sufyan Ats Thawri narrated for me: I leave a treasure of ten thousand dirhams that later will be judged by God, and for that, I love more, than I live with begging and become a burden to others.

By notice at the lives of the scholars and the priests, they provide a clear picture and the role model that is valuable to have a balance between the willingness for learning and living. Most of the prophets and apostles strive and work to sustain the continuity in spreading God Messages and Islam, for example, Nabi Zakaria (Zechariah) work as a carpenter, Nabi Idris (Enoch) crafting clothes and Nabi Daud (David) creating an armor. From previous example work is mean to capability to live independently is crucial for the messenger of God. Then, the eagerness to seek living well by trading, farming, and raise livestock is not dishonoring and not contrary to the attitude of resignation.

This is what is God messengers and the ancestor's mind so that they are classified as people who are persistent in working and determined in pursuing the result but they are also persistent and adaptable in seeking knowledge and spreading religious thought. There is no big deal for Muslims who work for a religious pronouncement or work for Muslim affairs and receive a reward from the job such as Umar bin Khattab when he uses to work as the 
Caliph, and fulfill his family needs from the Baitul mal.

A reflection on the role lives of the messengers of God and the salaf scholars, their activities in learning, and preaching do not neglect them to earn an appropriate gift to support their families' supply. So, we should be able to reflect them well in learning and the work for a living, and not supposed to be lazy to work without any logical reason. There are no specific requirements for Muslims to run businesses. The most important is the business run properly and obtained the results in the right way. Then, the work must be occupied and lived to full like joy, without any hesitation, and low-self esteem relate to the job that is most people considered it as a despicable and not undignified, whereas the core of value does not depend on the prestigious or whether work for multinational companies or get popularity and good position and vice versa, but the greatest effort considerably determined by the good deeds and the appropriate work in terms of Sharia and Islam.

As the characteristics of professional work according to M.Imadudin Abdurrahim (1993: 52) is as follows : a. Performing particular skill concerning the field, as well as proficiency in the use of equipment specified, is necessary to carry out the tasks that concerned with the field.

b. Having knowledge and experience as well as the intelligence to analyze a problem, and capability to understand the situation, quick, precise, and careful in taking the best decision.

c. Having foresight, so the ability is equipped to anticipate the problem at present.

d. Having a sovereign attitude based on self-belief and capability, open-minded, a good listener and respecting others, and conscious for the best personal decision that relates to his personality development.

Someone can perform as a professional at work and show some eager, high determination, and not just from a spontaneous stimulation from the outer self. The issue might be thoughtful when someone works and does not have the eagerness that may lead to a deficiency that harms him, employers, and society at all. God says: And say: "Work (righteousness): soon will Allah observe your work and His apostle and the believers: soon will ye be brought back to the knower of what is hidden and what is open: then will He show you the truth of all that ye did.." (At- Taubah: 105).

\section{Work Motivation for Muslims}

Work in terms of Islamic view has a great value. The main pillars such as zakat and Hajj are not possible to do for someone with no treasure. In general, the treasure will not occupy to someone that does not work. Work becomes mandatory, except for particular situations that are justified by the Shari'a. For that reason, someone's work will have advantages that remain best, by following with appropriate work ethic.

Work ethic is a value or spirit that drives one's work. It can figure as the soul or spirit of a charity. Islamic thoughts contain many instructions, commands, and encouragement for people to improve the work ethic among them; QS At- Taubah verse 105, QS Qashas verse 26, QS Al - Jumu'ah verse 10.

There are also several Prophetic Hadiths narrated by H. R Ahmad " The best work is man's work that done with his own hands and the transaction are appropriate way".

As well as the hadith of the Prophet who narrated by H. R Bukhari, "There is no person consumes good food, of which came from its own, because The God's Prophet, David takes food from his own ".

The intended meaning from the previous hadith above is for someone who works with honest and follows the guidance then God would replace them in heaven altogether with the prophets and the Muttaqien and God will give grace to those who spend the result of workings of by saving each of them, so they may sustain if someday they will live inadequately.

The work motivation for Muslims runs both horizontal and vertical. In horizontal, the visible motivation drives to develop the potential ability at inner-self, and the strong will to explore the benefits for others. While in the vertical side is intended to devote themselves to God. Motivation functions as a driver, a determinant of the direction, and the adjustments of scale priorities.

The Prophet said that the value of a work can be seen from the quality of "intention"(Al-Hadith ). People have to work for their own happiness, their family, and as well as to others. While Islam emphasizes the presence of humans in the world is to devote to God. To stimulate the change in society refers to heavy-duty progress. Even the case with a great barrier ahead requires sincerity to deal with it. In order to be able to live sincerely, it is necessity to have a good attitude and hard workers.

The working hard attitude is a gift from God to His servants as a social function. Social acts should be used to encourage advancement and development. The basic human needs must be accomplished by hard-working and it is a big challenge to make it work in a good way.

Working and looking for good things in a halal way is a struggle. But that things emphasize the existence of bound connected to values and norms of religion and devotion in the society. Individuals and society are struggling to stop unemployment both in general and in individuals. Therefore, Muslims are urged to change a life by an approach to social ways, such as long-live learning, persistence; trade; work; and so on. For someone will not be considered to be good if concerned about the Hereafter, but also think about the humankind.

Besides having adequate capability (kafa'ah) and trustworthy, someone is considered as a professional if he 
is always excited and concern at working. He also has a good work ethic (himmatul `amal). Islam encourages Muslims to always work hard and earnestly devote strength and ability to work.

Foremost encouragement for Muslims is the activity refers in Islamic perspectives as a part of worship, because the work is the implementation of one of the obligations, as described at the previous discussion, and the effort had earned from the work severity rated as noble. "It is no one of you to eat a meal which better than eating from his own work." (HR Baihaqi)

Islam also explains that working with earnest - according to several hadiths - even to purify e the sin that is unable to shed by the worship though.

"Whoever that feel exhausted at night as the effort of the skills in the day then at night the day was on forgivenes ." ( HR Ahmad ) "Absolutely, amongst sinful, there is a sin which can not be erased (redeemed) by (reward) shaum and prayer." Then he asked, "who can remove it, Ya Rasulullah ?" the Prophet replied, " Pain ( work) in the search for the subsistence of livelihood." (Narrated Abu Nu'aim )

"Indeed, among the acts of sin is no sin that is not be erased (redeemed) by (reward) prayers, alms (zakat), or hajj, but can redeem with suffering in seeking for livelihood." (HR Thabrani )

For this reason, God and his messengers give honor to Muslims who work hard or have a high work ethic and pray for blessings for him." Truly, Allah Ta 'ala likes to see His servants go to great lengths (fatigue) in seeking halal subsistence." (HR ad- Dailami ) "Ya Allah! Give a blessing to my people, the businesses are doing in the early days "(HR Tirmidhi )

The Prophet Muhammad even ever kissed the hand of his fellow friend Sa'd bin Mu'adh ra. when he saw the bare hand after working, as he said, "( This is ) two hands that loved God Almighty". Besides Muslims also be able to work hard because of their will to earn material and non-material rewards or awards such as salary or income, good career and recognition, and so on. On the other hand, Muslims willing to work hard because the worried about punishment from society, in the form of lower-income, an average career, and no recognition from peers. This can be done by following the provisions of Islamic thoughts and the principal motivation to work hard is to carry out the commands of Allah and His Messenger.

From the explanation above, it can be concluded that Muslims in carrying out every work must be keen and full of enthusiasm. In other words, work ethics should perform well. Muslims should be a smart worker, high discipline, fruitfulness, and novelty.

\section{Conclusion}

The Islamic work ethic is the habitual human character concerning employment arising from the faith or Aqeedah as fundamental life thought. Aqeedah was determined by understanding the teachings of revelation and logic that work together. The intended meaning relies on the definition and function which is a source of motivation, as well as a source of reference and value concerning work.

The Islamic thought has great potential as a motivation for the high Islamic work ethic, which is the origin of intrinsic motivation. The formed ethical work for someone is not able to separate from some influence factors. So that Islam's thoughts are potential to be executed that contribute to the psychological side that established and beyond the form of Islamic work ethic.

The work ethic through the Islamic perspective can interpret as a personal attitude that grows to a deep conviction that works is not only to glorify itself, showing humanity but also as a manifestation and devout deeds. So the work that is based on faith principles indicates the nature of a Muslim but at the same time advancing the dignity of himself as a servant of God who suffered a desire to make himself as a figure who can be trusted, to confirm himself as a trustworthy, and show an attitude of devotion

\section{References}

Abdurrahirn, M. Imadudin, 1993, Etos Kerja Profesional, Jakarta : Darma Mahardika.

Ahmad, Khursid, 2004, Etika Bisnis Islami, Yogyakarta : Akademi Manajemen Perusahaan YKPN.

Baqi, M.F.A. dan G. Makri, 1996, Terjemahan Al Lu' lu' wal Madan (Kumpulan Hadits yang Disepakati Bukhari dan Muslim), Surabaya : Penerbit Al Ikhlas.

Departemen Agama RI, 2008, AI-Qur'an Al Karim dan Terjemahannya, Semarang : Penerbit CV Toha Putra.

Madjid, Nurcholish, 1992, Islam : Doktrin dan Peradaban, Jakarta : Yayasan Wakaf Paramadina.

Rahardjo, Dawam, 1989, Etika Membangun Masyarakat Islam Modern, Yogyakarta : Graha Ilmu.

Rusli, M., 1992, Etos Kerja dan Pembangunan Ekonomi, Jakarta : Cetakan ke-5, LP3ES. 